\title{
Papers
}

\section{Folate and vitamin B-12 and risk of fatal cardiovascular disease: cohort study from Busselton, Western Australia}

\author{
Joseph Hung, John P Beilby, Matthew W Knuiman, Mark Divitini
}

\begin{abstract}
Objective To test the hypothesis that the incidence of fatal coronary heart disease and cardiovascular disease in a general population is related to serum and red cell folate and vitamin B-12 concentrations. Design Cohort study with follow up of 29 years. Setting Busselton, Western Australia. Participants 1419 men and 1531 women aged 20 to 90 years, who were alive more than three years after their participation in the 1969 Busselton health survey. 2314 (78.4\%) had no cardiovascular disease at the initial survey.

Main outcome measures Hazard ratios for fatal coronary heart disease and cardiovascular disease in men and women according to baseline concentrations of serum and red cell folate and serum vitamin B-12.

Results 213 men and 159 women died from coronary heart disease, and 342 men and 302 women died from cardiovascular disease. Serum and red cell folate concentrations showed a moderate positive correlation $(r=0.26, \mathrm{P}<0.001)$ but otherwise serum and red cell folate and serum B-12 concentrations were not strongly correlated with each other or with other standard risk factors. After age and standard risk factors were adjusted for, there was no independent association between folate and B-12 concentrations and death from coronary heart disease or cardiovascular disease in the full cohort or the subcohort with no cardiovascular disease at baseline. The multivariate adjusted hazard ratio for death from cardiovascular disease in the lowest versus the highest category of red cell folate concentration was 1.05 (95\% confidence interval 0.77 to 1.43 ) in men and 1.10 (0.81 to 1.51$)$ in women.
\end{abstract}

Conclusions These findings do not support the hypothesis that lower folate and B-12 concentrations increase the risk of fatal cardiovascular disease in a general population. The routine use of these vitamins for preventing cardiovascular disease should await evidence from clinical trials.

\section{Introduction}

Epidemiological studies have shown that moderate hyperhomocysteinaemia is an independent risk factor for coronary, cerebral, and peripheral vascular disease. ${ }^{12}$ Studies have also shown that moderately raised concentrations of homocysteine are prevalent in the general population and that an inverse relation exists between homocysteine concentration and concentrations of folate and vitamins B-6 and B-12. ${ }^{4}$ Randomised clinical trials have shown that low dose vitamin supplementation, particularly with folic acid, significantly lowers homocysteine concentrations. ${ }^{5}$ However, there are no clinical trial data that prove that lowering homocysteine concentrations prevents deaths from cardiovascular disease or coronary heart disease.

Several secondary prevention trials testing folic acid are under way, ${ }^{6}$ but primary prevention trials are problematic because they require much larger sample sizes and longer follow up. Potential trials are also complicated by the widespread introduction of grains and foods fortified with folate and by increasing recommendations for the use of folic acid supplements in cardiac patients and the general population. In the absence of proof from prevention trials, it is useful to seek evidence that circulating or dietary levels of folate and vitamin B-6 and $\mathrm{B}-12$ in the general population are related to incident cardiovascular disease. Prospective evidence linking these factors remains limited and inconsistent. ${ }^{7-12}$ The purpose of this cohort study was to test the hypothesis that an increased incidence of fatal coronary heart disease and cardiovascular disease was related to lower concentrations of serum and red cell folate and serum vitamin B-12 in a community population.

\section{Participants and methods}

Busselton is a seaside town in Western Australia with a predominantly white population. Cross sectional health surveys of adults listed on the electoral roll (enrolment to vote is compulsory in Australia) were undertaken every three years from 1966 to 1981 . This study is based on 1772 men and 1904 women aged 20 to 90 years who attended the 1969 survey, representing a $90 \%$ participation rate for the total adult population. The human research ethics committee, University of Western Australia, approved the study.

The methods of the surveys, including a detailed description of the study population, examination of participants, and laboratory methods have been described elsewhere. ${ }^{13}{ }^{14}$ In summary, the participants were asked to complete a comprehensive health and lifestyle questionnaire and to undergo various measurements and tests. Sitting blood pressure was measured by mercury sphygmomanometer after five minutes' rest. Body mass index was derived as weight

\section{Departments of Cardiology and Medicine, Sir Charles Gairdner Hospital, University of Western \\ Australia, Nedlands WA 6009, Australia Joseph Hung associate professor \\ PathCentre, QEII Medical Centre, Nedlands 6009, Australia \\ John P Beilby senior biochemist \\ Department of Public Health, University of Western Australia \\ Matthew W Knuiman associate professor Mark Divitini research associate Correspondence to: J Hung jhung@cyllene. uwa.edu.au}

bmj.com 2003;326:131 
(in kilograms) divided by the square of height (in metres). Details of smoking, alcohol consumption, diabetes, and use of antihypertensive drugs were obtained by questionnaire. Coronary heart disease was determined from the Rose questionnaire for angina and myocardial infarction and the electrocardiogram together with a self reported confirmation of a doctor's diagnosis of heart disease. ${ }^{15}$ Serum cholesterol concentrations were determined from a fasting blood sample. Serum and red cell folate and serum vitamin B-12 concentrations were measured in fresh samples by using automated microbiological assay systems ${ }^{16}{ }^{17}$ The within-run coefficient of variation was $1.5 \%$ for paired measurements of folate for concentrations ranging from 1.9 to $17.0 \mu \mathrm{g} /{ }^{16}$

\section{Outcome}

Data on deaths were available to 31 December 1998. Deaths among survey participants were identified by linkage to the death register. Survival was confirmed by linkage to the electoral roll and Telecom White Pages and through relatives. We ascertained vital status at 31 December 1998 for $98 \%$ of the cohort. The survival times for the remaining $2 \%$ were censored at the last time known to be alive. The underlying cause of death was determined from the death certificates by a nosologist at the Australian Bureau of Statistics using the international classification of diseases (ICD-9). Deaths were attributed to coronary heart disease if the underlying cause of death was coded 410-414 and to cardiovascular disease if the underlying cause of death had codes 410-459.

\section{Analysis of data}

There were 1486 men and 1570 women available for analysis after we excluded pregnant women and those with missing values for primary risk factors or adjustment variables. Of these, 67 men and 39 women died within three years of the 1969 survey and have also been omitted, leaving a total of 1419 men and

Table 1 Characteristics of subjects at baseline with survival time $\geqslant 3$ years. Values are numbers (percentages) of participants unless stated otherwise

\begin{tabular}{|c|c|c|c|c|}
\hline \multirow[b]{2}{*}{ Variable } & \multicolumn{2}{|c|}{ Total cohort } & \multicolumn{2}{|c|}{ Cohort free of cardiovascular disease } \\
\hline & Men $(n=1419)$ & Women ( $\mathrm{n}=1531)$ & Men $(n=1113)$ & Women $(n=1201)$ \\
\hline Mean (SD) age (years) & $48.4(15.7)$ & $47.9(15.3)$ & $46.6(15.2)$ & $45.9(14.8)$ \\
\hline Mean (SD) systolic blood pressure (mm Hg) & $133.6(20.0)$ & $131.2(22.5)$ & $132.3(19.5)$ & $128.8(21.3)$ \\
\hline Mean (SD) diastolic blood pressure $(\mathrm{mm} \mathrm{Hg})$ & $80.6(13.4)$ & $77.8(13.8)$ & $80.0(13.2)$ & $76.6(13.0)$ \\
\hline Mean (SD) body mass index & $24.9(3.2)$ & $24.6(4.0)$ & $24.7(3.1)$ & $24.3(3.8)$ \\
\hline Mean (SD) serum cholesterol $(\mathrm{mmol} / \mathrm{l})$ & $5.62(1.04)$ & $5.89(1.17)$ & $5.58(1.02)$ & $5.83(1.16)$ \\
\hline Mean (SD) white cell count $\left(10^{9} / l\right)$ & $7.3(1.9)$ & $6.9(1.8)$ & $7.3(1.9)$ & $6.9(1.8)$ \\
\hline \multicolumn{5}{|l|}{ Smoking habit: } \\
\hline Never smoked & $380(26.8)$ & $971(63.4)$ & $317(28.5)$ & $740(61.6)$ \\
\hline Former smoker & $393(27.7)$ & $188(12.3)$ & $299(26.9)$ & $153(12.7)$ \\
\hline Mild smoker & $297(20.9)$ & $204(13.3)$ & $223(20.0)$ & $170(14.2)$ \\
\hline Heavy smoker & $350(24.7)$ & $168(11.0)$ & $274(24.6)$ & $138(11.4)$ \\
\hline Diabetes treatment & $13(0.9)$ & $13(0.8)$ & $8(0.7)$ & $9(0.75)$ \\
\hline Blood pressure treatment & $45(3.2)$ & $106(6.9)$ & $26(2.3)$ & $53(4.4)$ \\
\hline \multicolumn{5}{|l|}{ Alcohol use: } \\
\hline Non-drinker & $146(10.3)$ & $510(33.3)$ & $119(10.7)$ & $390(32.5)$ \\
\hline Former drinker & $81(5.7)$ & $1338.7)$ & $51(4.6)$ & $98(8.2)$ \\
\hline Light drinker & $749(52.8)$ & $799(52.2)$ & $592(53.2)$ & $640(53.3)$ \\
\hline Heavy drinker & $443(31.2)$ & $87(5.7)$ & $351(31.5)$ & $73(6.1)$ \\
\hline \multicolumn{5}{|l|}{ History of coronary heart disease: } \\
\hline None & $1138(80.2)$ & $1223(79.9)$ & - & - \\
\hline Possible & $146(10.3)$ & $174(11.4)$ & - & - \\
\hline Definite & $135(9.5)$ & $133(8.7)$ & - & - \\
\hline Leg claudication & $25(1.8)$ & $26(1.7)$ & - & - \\
\hline History of stroke & $12(0.8)$ & $11(0.7)$ & - & - \\
\hline Menopause & - & $720(47)$ & - & $503(41.9)$ \\
\hline Mean (SD) serum folate $(\mu \mathrm{g} / \mathrm{l})$ & $5.27(2.35)$ & $5.02(2.42)$ & $5.25(2.30)$ & $5.05(2.44)$ \\
\hline \multicolumn{5}{|l|}{ Serum folate quarter $(\mu \mathrm{g} / \mathrm{l})$ : } \\
\hline 0 to 2.99 & $140(9.9)$ & $231(15.1)$ & $108(9.7)$ & $181(15.1)$ \\
\hline 3.00 to 4.49 & $471(33.2)$ & $540(35.3)$ & $376(33.8)$ & $423(35.2)$ \\
\hline 4.50 to 5.99 & $385(27.1)$ & $337(22.0)$ & $299(26.9)$ & $264(22.0)$ \\
\hline$\geqslant 6.00$ & $424(29.9)$ & $423(27.6)$ & $329(29.6)$ & $333(27.7)$ \\
\hline Mean (SD) red cell folate $(\mu \mathrm{g} / \mathrm{l})$ & $307.7(127.6)$ & $283.5(130.2)$ & $308.1(128.4)$ & $283.3(130.2)$ \\
\hline \multicolumn{5}{|l|}{ Red cell folate quarter $(\mu \mathrm{g} / \mathrm{l})$ : } \\
\hline 0 to 199.9 & $277(19.5)$ & $433(28.3)$ & $223(20.0)$ & $337(28.1)$ \\
\hline 200 to 274.9 & $397(28.0)$ & $404(26.4)$ & $309(27.8)$ & $323(26.9)$ \\
\hline 275 to 349.9 & $282(19.9)$ & $314(20.5)$ & $221(19.9)$ & $241(20.1)$ \\
\hline$\geqslant 350$ & $461(32.5)$ & $378(24.7)$ & $359(32.3)$ & $300(24.9)$ \\
\hline Mean (SD) vitamin B-12 (ng/l) & $366.3(132.3)$ & $360.0(147.7)$ & $369.4(134.2)$ & $358.0(147.6)$ \\
\hline \multicolumn{5}{|l|}{ Vitamin B-12 quarter $(\mathrm{ng} / \mathrm{l})$ : } \\
\hline 0 to 269.9 & $306(21.6)$ & $404(26.4)$ & $237(21.3)$ & $321(26.7)$ \\
\hline 270 to 329.9 & $338(23.8)$ & $357(23.3)$ & $260(3.4)$ & $286(23.8)$ \\
\hline 330 to 389.9 & $263(18.5)$ & $282(18.4)$ & $200(18.0)$ & $220(18.3)$ \\
\hline$\geqslant 390$ & $512(36.1)$ & $489(31.8)$ & 415 (37.3) & $374(31.1)$ \\
\hline
\end{tabular}


1531 women. A total of 1113 men and 1201 women (78.4\% of cohort) had no history of coronary heart disease, leg claudication, or stroke at initial survey and were considered free from cardiovascular disease. We analysed data from this subcohort separately.

The risk factors of primary interest were serum and red cell folate concentrations and serum B-12 concentration. We also included other baseline risk factors for cardiovascular disease in the multivariate analysis: age, systolic and diastolic blood pressure, body mass index, serum cholesterol concentration, white cell count, smoking, menopause (in women), treatment for diabetes, treatment for hypertension, alcohol intake, and history of coronary heart disease, stroke, or leg claudication. $^{18}{ }^{19}$

We used Cox proportional hazards regression analysis of survival to death or end of follow up to assess the influence of primary risk factors after adjustment for age only and also after adjustment for age and other risk factors. ${ }^{19}{ }^{19}$ As the age adjusted and multivariate adjusted results were similar, only the multivariate results are reported. We did separate analyses for men and women and for the whole cohort and the subcohort who had no cardiovascular disease at baseline. Vitamin concentrations were examined as continuous variables and also in categories. We used $\log$ (base e) transformations of folate and B-12 concentrations as continuous variables because of skewed distributions. The categories were based on approximate quarters for the entire study group, with the quartiles rounded and the same categories used for all groups analysed. The $\mathrm{P}$ values from the models that used the vitamin level as a continuous variable are presented as trend $\mathrm{P}$ values. Results from the models that used vitamin level as a categorical variable are reported as adjusted hazard ratios (relative risks) with 95\% confidence intervals relative to the highest group. We also did a survival analysis restricted to 15 years of follow up.

\section{Results}

Table 1 shows the baseline risk characteristics of the cohort. The average age was about 48 years and the risk factor characteristics are typical of population samples surveyed around that time. Serum folate and red cell folate concentrations showed a moderate positive correlation $(r=0.26 ; \mathrm{P}<0.001)$ but neither serum nor red cell folate and vitamin B-12 concentrations were correlated with each other or with other risk factors (data not shown).

After 29 years' follow up, 665 men and 537 women had died (excluding subjects who died within three years of initial survey). Death was due to cardiovascular disease in 342 men and 302 women and to coronary heart disease in 213 men and 159 women. In the subcohort of participants without cardiovascular disease, 475 men and 362 women had died; deaths were due to cardiovascular disease in 226 men and 187 women and to coronary heart disease in 131 men and 98 women.

Tables 2 and 3 show the multivariate adjusted hazard ratios for folate and vitamin B-12 quarters in relation to deaths from all causes, cardiovascular disease, and coronary heart disease. There was no consistent or significant pattern of relative risk for serum and red cell folate and serum B-12 concentrations in men and women in the full cohort. Among women in the subcohort without cardiovascular disease, there was a generally inverse association between serum folate concentrations and risk of death, but the only significant relative risk was for all cause mortality, and the trend $P$ value was not significant at the $5 \%$ level.

Among men in the subcohort without cardiovascular disease, the trend model suggested an unexpected positive association between serum folate concentration and risk of death from cardiovascular disease $(\mathrm{P}=0.05)$, but the categorical model showed no association. Further exploration revealed that a subgroup of 85 men ( $7 \%$ of the disease-free cohort)

Table 2 Adjusted hazard ratios* (95\% confidence intervals) for death among participants surviving three years after baseline according to quarters of serum and red cell folate and serum vitamin B-12 concentrations

\begin{tabular}{|c|c|c|c|c|c|c|}
\hline & \multicolumn{3}{|c|}{ Men $(n=1419)$} & \multicolumn{3}{|c|}{ Women $(n=1531)$} \\
\hline & All deaths & $\begin{array}{l}\text { Cardiovascular } \\
\text { disease deaths }\end{array}$ & $\begin{array}{l}\text { Coronary heart } \\
\text { disease deaths }\end{array}$ & All deaths & $\begin{array}{l}\text { Cardiovascular } \\
\text { disease deaths }\end{array}$ & $\begin{array}{l}\text { Coronary heart } \\
\text { disease deaths }\end{array}$ \\
\hline \multicolumn{7}{|c|}{ Serum folate $(\mu \mathrm{g} / \mathrm{l})$ : } \\
\hline 0 to 2.99 & 1.07 (0.80 to 1.43$)$ & 1.06 (0.70 to 1.60$)$ & 1.10 (0.63 to 1.91) & 1.19 (0.88 to 1.61$)$ & 1.04 (0.69 to 1.56$)$ & 1.14 (0.65 to 2.03$)$ \\
\hline 3.00 to 4.49 & 1.13 (0.93 to 1.38$)$ & 1.23 (0.94 to 1.62$)$ & 1.44 (1.01 to 2.06$)$ & 1.15 (0.93 to 1.43$)$ & $0.97(0.73$ to 1.30$)$ & $1.13(0.77$ to 1.67$)$ \\
\hline 4.50 to 5.99 & 0.95 (0.78 to 1.17) & 0.91 (0.68 to 1.21 ) & 1.34 (0.92 to 1.89) & 1.07 (0.84 to 1.35$)$ & $0.88(0.64$ to 1.20$)$ & 0.95 (0.62 to 1.47$)$ \\
\hline$\geqslant 6.00 \dagger$ & 1.00 & 1.00 & 1.00 & 1.00 & 1.00 & 1.00 \\
\hline Trend $P$ value & 0.93 & 0.81 & 0.58 & 0.23 & 0.79 & 0.80 \\
\hline \multicolumn{7}{|c|}{ Red cell folate $(\mu \mathrm{g} / \mathrm{l})$ : } \\
\hline 0 to 199.9 & 1.03 (0.83 to 1.29) & 1.05 (0.77 to 1.43 ) & 1.26 (0.86 to 1.85$)$ & 1.15 (0.91 to 1.46$)$ & $1.10(0.81$ to 1.51$)$ & 1.00 (0.65 to 1.53$)$ \\
\hline 200 to 274.9 & 1.00 (0.81 to 1.22$)$ & 1.03 (0.78 to 1.36$)$ & 1.07 (0.75 to 1.53 ) & 0.97 (0.76 to 1.24$)$ & 0.89 (0.64 to 1.24$)$ & 0.75 (0.48 to 1.18$)$ \\
\hline 275 to 349.9 & 1.14 (0.92 to 1.42$)$ & 0.89 (0.64 to 1.22$)$ & 0.90 (0.60 to 1.36$)$ & 1.11 (0.86 to 1.42$)$ & 1.00 (0.71 to 1.39$)$ & 0.93 (0.60 to 1.46$)$ \\
\hline$\geqslant 350 \dagger$ & 1.00 & 1.00 & 1.00 & 1.000 & 1.00 & 1.00 \\
\hline Trend $P$ value & 0.72 & 0.80 & 0.35 & 0.92 & 0.93 & 0.63 \\
\hline \multicolumn{7}{|c|}{ Vitamin B-12 (ng/l): } \\
\hline 0 to 269.9 & 0.99 (0.80 to 1.22) & 1.14 (0.85 to 1.53$)$ & 1.09 (0.74 to 1.60$)$ & 1.04 (0.83 to 1.31$)$ & 0.88 (0.65 to 1.20$)$ & 0.74 (0.48 to 1.14$)$ \\
\hline 270 to 329.9 & 1.10 (0.89 to 1.35$)$ & 1.23 (0.92 to 1.65$)$ & 1.30 (0.90 to 1.89$)$ & 1.00 (0.78 to 1.27$)$ & 0.94 (0.68 to 1.29) & 0.82 (0.52 to 1.27$)$ \\
\hline 330 to 389.9 & 0.90 (0.71 to 1.14$)$ & 0.87 (0.62 to 1.23 ) & 1.09 (0.72 to 1.65) & 0.96 (0.75 to 1.24$)$ & 0.89 (0.64 to 1.25$)$ & 0.88 (0.56 to 1.37$)$ \\
\hline$\geqslant 390 \dagger$ & 1.00 & 1.00 & 1.00 & 1.00 & 1.00 & 1.00 \\
\hline Trend $\mathrm{P}$ value & 0.65 & 0.24 & 0.30 & 0.86 & 0.50 & 0.37 \\
\hline
\end{tabular}

*Hazard ratios are adjusted for age, systolic and diastolic blood pressure, body mass index, cholesterol concentration, white cell count, smoking, treatment for diabetes, treatment for hypertension, alcohol intake, and history of coronary heart disease, stroke, or leg claudication.

†Reference group for hazard ratio. 
Table 3 Adjusted hazard ratios* (95\% confidence intervals) for death among participants who had no cardiovascular disease at baseline and who survived three years according to quarters of serum and red cell folate and serum vitamin B-12 concentrations

\begin{tabular}{|c|c|c|c|c|c|c|}
\hline & \multicolumn{3}{|c|}{ Men $(n=1113)$} & \multicolumn{3}{|c|}{ Women ( $n=1201)$} \\
\hline & All deaths & $\begin{array}{l}\text { Cardiovascular } \\
\text { disease deaths }\end{array}$ & $\begin{array}{l}\text { Coronary heart } \\
\text { disease deaths }\end{array}$ & All deaths & $\begin{array}{l}\text { Cardiovascular } \\
\text { disease deaths }\end{array}$ & $\begin{array}{l}\text { Coronary heart } \\
\text { disease deaths }\end{array}$ \\
\hline \multicolumn{7}{|c|}{ Serum folate $(\mu \mathrm{g} / \mathrm{l})$ : } \\
\hline 0 to 2.99 & $0.88(0.61$ to 1.26$)$ & $0.77(0.45$ to 1.33$)$ & 0.84 (0.40 to 1.77$)$ & 1.51 (1.03 to 2.21$)$ & $1.39(0.79$ to 2.46$)$ & 1.35 (0.61 to 3.10$)$ \\
\hline 3.00 to 4.49 & $1.00(0.79$ to 1.26$)$ & 0.98 (0.70 to 1.38) & 1.15 (0.72 to 1.84$)$ & 1.23 (0.95 to 1.59$)$ & 1.05 (0.73 to 1.51) & $1.11(0.68$ to 1.81$)$ \\
\hline 4.50 to 5.99 & $1.00(0.79$ to 1.28$)$ & 0.98 (0.69 to 1.39) & 1.67 (1.07 to 2.60$)$ & 1.11 (0.83 to 1.49$)$ & $1.04(0.70$ to 1.55$)$ & 1.10 (0.64 to 1.89$)$ \\
\hline$\geqslant 6.00 \dagger$ & 1.00 & 1.00 & 1.00 & 1.00 & 1.00 & 1.00 \\
\hline Trend $\mathrm{P}$ value & 0.23 & 0.05 & 0.47 & 0.08 & 0.64 & 0.69 \\
\hline \multicolumn{7}{|c|}{ Red cell folate $(\mu \mathrm{g} / \mathrm{l})$ : } \\
\hline 0 to 199.9 & 0.96 (0.74 to 1.25$)$ & $1.06(0.73$ to 1.53$)$ & 1.16 (0.71 to 1.91$)$ & $1.08(0.81$ to 1.45$)$ & 1.07 (0.72 to 1.59) & 0.91 (0.53 to 1.54) \\
\hline 200 to 274.9 & 0.98 (0.77 to 1.25$)$ & $1.04(0.73$ to 1.46$)$ & 1.17 (0.75 to 1.84$)$ & $1.01(0.75$ to 1.36$)$ & 0.96 (0.63 to 1.47$)$ & $0.73(0.41$ to 1.31$)$ \\
\hline 275 to 349.9 & $1.13(0.87$ to 1.47$)$ & $0.92(0.61$ to 1.39$)$ & 0.96 (0.55 to 1.67$)$ & $0.98(0.73$ to 1.33$)$ & 0.76 (0.50 to 1.17$)$ & $0.71(0.40$ to 1.24$)$ \\
\hline$\geqslant 350 \dagger$ & 1.00 & 1.00 & 1.00 & 1.00 & 1.00 & 1.00 \\
\hline Trend $\mathrm{P}$ value & 0.83 & 0.79 & 0.42 & 0.72 & 0.75 & 0.82 \\
\hline \multicolumn{7}{|c|}{ Vitamin B-12 (ng/l): } \\
\hline 0 to 269.9 & 1.05 (0.82 to 1.35) & $1.16(0.81$ to 1.66$)$ & 1.17 (0.72 to 1.91$)$ & 0.94 (0.71 to 1.25$)$ & 0.76 (0.51 to 1.15$)$ & 0.68 (0.39 to 1.21$)$ \\
\hline 270 to 329.9 & 1.25 (0.98 to 1.60$)$ & 1.44 (1.01 to 2.05) & 1.65 (1.04 to 2.62$)$ & $1.03(0.78$ to 1.36$)$ & 1.02 (0.69 to 1.49) & $0.92(0.55$ to 1.54$)$ \\
\hline 330 to 389.9 & $1.02(0.77$ to 1.34$)$ & 0.83 (0.53 to 1.28$)$ & 1.09 (0.63 to 1.88$)$ & 0.77 (0.56 to 1.06) & 0.68 (0.44 to 1.07) & 0.68 (0.37 to 1.24$)$ \\
\hline$\geqslant 390 \dagger$ & 1.00 & 1.00 & 1.00 & 1.00 & 1.00 & 1.00 \\
\hline Trend $\mathrm{P}$ value & 0.85 & 0.35 & 0.46 & 0.62 & 0.21 & 0.42 \\
\hline
\end{tabular}

*Adjusted for age, systolic and diastolic blood pressure, body mass index, cholesterol concentration, white cell count, smoking, treatment for diabetes, treatment for hypertension, and alcohol intake.

†Reference group for hazard ratio.

with serum folate concentrations $>9 \mu \mathrm{g} / \mathrm{l}$ had about double the risk of death from cardiovascular disease compared with men with concentrations $<9 \mu \mathrm{g} / \mathrm{l}$. When these men were removed from the analysis, there was no longer evidence of a trend for death from cardiovascular disease $(\mathrm{P}=0.66)$. There was no evidence of a significant relation between red cell folate concentration and death from all causes, cardiovascular disease, or coronary heart disease. The relative risk was close to unity for the lowest compared with the highest group in both men and women. We also found no significant relation between vitamin concentrations and deaths from cardiovascular or coronary heart disease with survival analysis restricted to 15 years (data not shown).

\section{Discussion}

We found no evidence of an independent association between folate or vitamin B-12 concentrations and death from cardiovascular or coronary heart disease. The trends in risk factors and mortality in the Busselton population are similar to those in other parts of Australia. ${ }^{14}$ In addition, adjusted estimates of relative risk of coronary heart disease and stroke in the Busselton population seem consistent with estimates in other populations of similar age and ethnicity. ${ }^{18-20}$ Vital status could be ascertained for $98 \%$ of the cohort after 29 years, and the numbers of observed deaths from cardiovascular and coronary heart disease were sufficiently large for reliable statistical analyses. We excluded participants who died within the first three years of survey to limit the possibility of reverse causality when examining the association between vitamin concentration and mortality.

The 1969 Busselton health survey measured serum and red cell folate and serum vitamin B-12 concentrations as a means of estimating the nutritional status of the population. ${ }^{17}$ Folate and B-12 nutrition seemed to be generally sufficient, with only $3.1 \%$ of the population having a reduced folate and $0.4 \%$ having a reduced B-12 concentration based on the normal reference intervals for red cell folate $(115-600 \mu \mathrm{g} / \mathrm{l})$ and serum B-12 (160-850 ng/l). ${ }^{17}$ The measured vitamin levels cannot be equated to values obtained with current assay methods. However, the absolute vitamin concentrations were unimportant as our analysis was based on estimating relative risks.

\section{Folate}

Previous studies have not measured red cell folate concentrations. Red cell folate indicates tissue folate status and reflects folate turnover over the preceding two to three months. ${ }^{21}$ It is a more reliable indicator of long term folate intake than serum folate, which has a high intraindividual variability because it reflects intake only in the preceding few days. ${ }^{21}$ This explains why we found only a modest correlation between red cell and serum folate concentrations in our population.

Studies examining the association between serum or dietary folate concentrations and coronary heart disease have produced inconsistent results (table 4). Morrison et al found a significant inverse association between serum folate concentration and 15 year mortality from coronary heart disease, especially in women. ${ }^{7}$ However, they found no association between dietary folate consumption and risk of fatal coronary heart disease. Other cohort studies with follow up periods ranging from 3.3 to 20 years have found no significant increase in risk of non-fatal or fatal coronary heart disease for participants in the lowest versus highest group of serum folate concentration (table 4). ${ }^{8-10}$ The high intraindividual variability of serum folate measurements may have diluted any observed association with risk of coronary heart disease in these studies as well as in our study, which found an inverse (but not significant) association between serum folate concentration and fatal cardiovascular disease in women who had no cardiovascular disease at baseline. We do not have replicate measure- 
Table 4 Cohort studies of association of circulating and dietary folate concentrations with risk of coronary heart disease

\begin{tabular}{|c|c|c|c|c|c|}
\hline Study (Reference) & Study population & Age range (years) & $\begin{array}{l}\text { Mean follow up } \\
\text { (years) }\end{array}$ & No of cases & $\begin{array}{l}\text { Adjusted relative risk } \\
(95 \% \mathrm{CI})\end{array}$ \\
\hline Morrison et al, $1996^{7}$ & $\begin{array}{l}5056 \text { members of the } \\
\text { general population }\end{array}$ & $35-79$ & 15 & $\begin{array}{l}165 \text { fatal coronary heart } \\
\text { disease }\end{array}$ & $\begin{array}{c}1.69(1.10 \text { to } 2.61) \text { for } \\
\text { lowest } v \text { highest quarter of } \\
\text { serum folate }\end{array}$ \\
\hline Chasan-Taber et al, $1996^{8}$ & 14916 male physicians & $40-84$ & 7.5 & 333 myocardial infarctions & $\begin{array}{c}1.4(0.9 \text { to } 2.3) \text { for lowest } v \\
\text { highest fifth of plasma } \\
\text { folate }\end{array}$ \\
\hline Folsom et al, $1998^{9}$ & $\begin{array}{l}15792 \text { members of the } \\
\text { general population }\end{array}$ & $45-64$ & 3.3 & $\begin{array}{l}232 \text { fatal and non-fatal } \\
\text { coronary heart disease }\end{array}$ & $\begin{array}{l}1.5(0.67 \text { to } 3.33) \text { for } \\
\text { lowest } v \text { highest fifth of } \\
\text { plasma folate }\end{array}$ \\
\hline Ford et al, $1998^{10}$ & $\begin{array}{l}2657 \text { members of the } \\
\text { general population }\end{array}$ & $25-74$ & 19 & 873 coronary heart disease & $\begin{array}{c}1.04(0.86 \text { to } 1.85) \text { for } \\
\text { lowest } v \text { highest quarter of } \\
\text { serum folate }\end{array}$ \\
\hline Rimm et al, $1998^{11}$ & 80082 female nurses & $30-55$ & 14 & $\begin{array}{c}939 \text { myocardial infarction } \\
\text { and fatal coronary heart } \\
\text { disease }\end{array}$ & $\begin{array}{l}1.45(1.18 \text { to } 1.82) \text { for } \\
\text { lowest } v \text { highest fifth of } \\
\text { dietary folate intake }\end{array}$ \\
\hline Voutilainen et al, $2001^{12}$ & 1980 Finnish men & $42-60$ & 10 & 199 acute coronary events & $\begin{array}{l}2.22(1.23 \text { to } 4.00) \text { for } \\
\text { lowest } v \text { highest fifth of } \\
\text { dietary folate intake }\end{array}$ \\
\hline
\end{tabular}

ments of serum folate over time in our population and so cannot adjust our estimates of relative risk for this regression dilution effect.

By contrast, the US Nurses' health study ${ }^{11}$ and the Kuopio ischaemic heart disease risk factor $\operatorname{study}^{12}$ of Finnish men found a significant inverse association between dietary folate intake and coronary heart disease events over 14 and 10 years respectively. However, these results need to be interpreted with caution as a high folate intake from food and vitamin supplements may also be related to other dietary factors or unmeasured risk behaviours that are independently associated with coronary heart disease.

\section{Vitamin B-12}

We found no association between vitamin B-12 concentration and death from cardiovascular or coronary heart disease. This may not be surprising given that vitamin B-12 supplementation has a relatively small effect on homocysteine concentration ${ }^{45}$ and B-12 deficiency is uncommon in the general population, being usually related to a problem of absorption rather than nutrition. Other cohort studies have not measured serum B-12 concentrations. However, a meta-analysis of randomised trials estimated that supplementation with folic acid and vitamin B-12 together could be expected to reduce basal homocysteine concentration by about a third, whereas B-6 supplementation did not have a significant additional effect. ${ }^{5}$ Vitamin B-6 concentrations were not measured in our cohort. Vitamin B-6 reduces homocysteine concentration predominantly after methionine loading, but there remains no evidence from clinical trials that vitamin B-6 reduces the risk of cardiovascular disease in the general population.

\section{Implications}

Our negative findings together with the inconsistent results of previous cohort studies leave many question unanswered about the effect of folate and vitamin B-12 on homocysteine concentrations and risk of cardiovascular disease in the general population. The epidemiological data for homocysteine as a risk factor for cardiovascular disease is strong, and clinical trials have shown that homocysteine concentrations can be lowered by safe and inexpensive doses of folic acid and vitamin B-12. Nevertheless, the lesson learnt from ran-

\section{What is already known on this topic}

Moderate hyperhomocysteinaemia is thought to be an independent risk factor for cardiovascular disease

High homocysteine concentrations in the general population are mainly due to insufficient folate and $\mathrm{B}$ vitamin concentrations

Evidence linking serum or dietary folate and B vitamin levels to incident cardiovascular disease is inconclusive

\section{What this study adds}

A large community cohort followed for 29 years showed no independent association of baseline serum and red cell folate and serum B-12 concentrations with mortality from cardiovascular disease

Vitamin therapy to lower homocysteine concentrations should not be routinely recommended in the general population until the benefit is proved by controlled clinical trials

domised trials of $\beta$-carotene and vitamin $\mathrm{E}^{22}$ is that the seemingly compelling benefits seen in observational studies are often contradicted by the results of clinical trials.

Our results do not argue against public health efforts to raise folate consumption in the general population by increased intake of fruits, vegetables, and fortified grains and cereals. ${ }^{23}$ However, use of vitamin supplements to lower homocysteine concentrations should not be routinely recommended in the general population for prevention of cardiovascular disease until their benefit is proved by controlled clinical trials.

We thank the Busselton Population Medical Research Foundation for access to the Busselton health survey data and the Busselton community for their longstanding cooperation and support for the Busselton health study.

Contributors: JH formulated the hypothesis, contributed to the study plan and interpretation of results, and wrote the manuscript. JPB and MK contributed to the data analysis plan, interpretation of results, and the editing and final approval of manuscript. MD carried out the statistical analysis and 
contributed to the interpretation of results, and editing and final approval of manuscript. JH is the guarantor.

Funding: None.

Competing interests: None declared.

1 Boushey CJ, Beresford SA, Omenn GS, Motulsky AG. A quantitative assessment of plasma homocysteine as a risk factor for vascular disease. Probable benefits of increasing folic acid intakes. JAMA 1995;274:104957.

2 Eikelboom JW, Lonn E, Genest J Jr, Hankey G, Yusuf S. Homocyst(e)ine and cardiovascular disease: a critical review of the epidemiologic evidence. Ann Intern Med 1999;131:363-75.

3 Selhub J. Jacques PF, Wilson PW, Rush D, Rosenberg IH. Vitamin status and intake as primary determinants of homocysteinemia in an elderly population. JAMA 1993;270:2693-8.

4 Ubbink JB. Vitamin nutrition status and homocysteine: an atherogenic risk factor. Nutr Rev 1994;52:383-7.

5 Homocysteine Lowering Trialists' Collaboration. Lowering blood homocysteine with folic acid based supplements: meta-analysis of randomised trials. BMJ 1998;316:894-8.

6 Clarke R, Collins R. Can dietary supplements with folic acid or vitamin B6 reduce cardiovascular risk? Design of clinical trials to test the homocysteine hypothesis of vascular disease. J Cardiovasc Risk 1998;5:249-55.

7 Morrison HI, Schaubel D, Desmeules M, Wigle DT. Serum folate and risk of fatal coronary heart disease. JAMA 1996;275:1893-6.

8 Chasan-Taber L, Selhub J, Rosenberg IH, Malinow MR, Terry P, Tishler $\mathrm{PV}$, et al. A prospective study of folate and vitamin $\mathrm{B} 6$ and risk of infarction in US physicians. J Am Coll Nutr 1996;15:136-42.

9 Folsom AR, Nieto FJ, McGovern PG, Tsai MY, Malinow MR, Eckfeldt JH, et al. Prospective study of coronary heart disease incidence in relation to
fasting total homocysteine, related genetic polymorphisms, and B vitamins: the atherosclerosis risk in communities (ARIC) study. Circulation 1998;98:204-10.

10 Ford ES, Byers TE, Giles WH. Serum folate and chronic disease risk: findings from a cohort of United States adults. Int J Epidemiol 1998;27:592-8.

11 Rimm EB, Willett WC, Hu FB, Sampson L, Colditz GA, Manson JE, et al. Folate and vitamin B6 from diet and supplements in relation to risk of coronary heart disease among women. JAMA 1998;279:359-64.
12 Voutilainen S, Rissanen TH, Virtanen J, Lakka TA, Salonen JT, Kuopio Ischemic Heart Disease Risk Factor Study Group. Low dietary folate intake is associated with an excess incidence of acute coronary events. Circulation 2001;103:2674-80.

13 Cullen KJ. Mass health examinations in the Busselton population, 1966 to 1970 . Med J Aust 1972;2:714-8.

14 Knuiman MW, Jamrozik K, Welborn TA, Bulsara MK, Divitini ML, Whittall DE. Age and secular trends in risk factors for cardiovascular disease in Busselton. Aust J Public Health 1995; 19:375-82.

15 Welborn TA, Cumpston GN, Cullen KJ. The prevalence of coronary heart disease and associated factors in an Australian rural community. Am J Epidemiol 1969;89:521-36.

16 Millbank L, Davis RE, Rawlins M, Waters AH. Automation of the assay of folate in serum and whole blood. J Clin Path 1970;23:54-9.

17 Davis RE. Serum vitamin levels and human nutrition. Proc Nutr Soc Aust 1979;4:45-52.

18 Knuiman MW, Vu HT, Bartholomew HC. Multivariate risk estimation for coronary heart disease: the Busselton health study. Aust NZ J Public Health 1998;22:747-53.

19 Knuiman MW, Vu HT. Risk factors for stroke mortality in men and women: The Busselton study. J Cardiovasc Risk 1996;3:447-52.

20 Knuiman MW, Vu HT. Prediction of coronary heart disease mortality in Busselton, Western Australia: an evaluation of the Framingham, national health epidemiologic follow up study, and WHO ERICA risk scores. $J$ Epidemiol Commun Health 1997;51:515-9.

21 Babior BM. The megaloblastic anemias. In: Beutler E, Lichtman M, Coller B, Kipps T, Seligsohn U, eds. Williams hematology. 6th ed. Chicago: McGraw-Hill, 2001:425-45.

22 Lonn E. Do antioxidant vitamins protect against atherosclerosis? The proof is still lacking. J Am Coll Cardiol 2001;38:1795-8.

23 Malinow MR, Bostom AG, Krauss RM. Homocyst(e)ine, diet, and cardiovascular diseases: a statement for healthcare professionals from the nutrition committee, American Heart Association. Circulation 1999;99:178-82.

(Accepted 26 September 2002) 